\title{
CLASSIFYING RESIDENTS' ROLES AS ONLINE PLACE-AMBASSADORS
}

Sanae Uchinaka Northumbria University.

Vignesh Yoganathan University of Bradford.

Victoria-Sophie Osburg (corresponding author) University of Hull.

Address: Hull University Business School, Cottingham Road, Hull HU6 7RX

Email: v.osburg@hull.ac.uk

\begin{abstract}
Residents are pivotal in the competitiveness of tourism destinations. Yet, their role as place-brand ambassadors needs better understanding, particularly in relation to social media, which directly link visitors to residents through user-generated-content (UGC). This paper explores residents' roles as place-brand ambassadors on Twitter, using the case of Onomichi (Japan), where decreasing population meets economic dependence on tourism. From a content analysis of residents' tweets, four distinct roles are identified, and corresponding types of content are mapped on a twodimensional continuum based on direct vs. indirect word-of-mouth and the level of sentiment. Authors discuss implications for Destination Management Organizations (DMOs). Findings highlight the increasingly shifting role of residents towards being primary sources of place-marketing, especially due to social media, and as active proponents (rather than passive targets) of place-branding in the digital age. Such organic place-marketing may be the key to sustaining tourism in the face of rising antitourist sentiments worldwide.
\end{abstract}

\section{Keywords}

residents, place marketing, destination branding, word-of-mouth, social media 


\section{Classifying residents' roles as online place-ambassadors}

\section{Introduction}

The role of residents has been gaining increasing attention due to residents' detailed knowledge about a place (Zenker et al., 2017) and the diversity of roles they can assume in promoting a place's attractiveness to main target groups (Braun et al., 2013; Young et al., 2007). Residents are an influential source of travel destination-related information, even when compared to frequent travelers (Arsal et al., 2010). Nevertheless, only a few studies have given detailed consideration to the types of residents in this context; for example by further subdividing them into current residents, expatriates, and potential residents (Kotsi et al., 2016). As such, there is room for development in our understanding of the variety of residents' roles, especially in conjunction with the factors that motivate the behavior of place-brand ambassadors. This paper therefore aims to uncover the role(s) of residents in place marketing in the context of a medium-sized city in Japan, of which the population is dwindling, and economic sustainability is reliant on tourism. Our research examines residents' actual online behavior, behavioral intentions, and role-differences to develop a classification of residents' roles as online place-ambassadors - i.e. individuals who positively endorse and promote a place to visitors and other stakeholders via online platforms or social media. Whilst most previous studies focus on Destination Management Organizations (DMOs) and their influence on tourists' choices, this study emphasizes the importance of better understanding residents' role in the place branding context.

There is much to be understood about the role of residents and their social media usage, in terms of place marketing and tourism. Social media are acknowledged to be one of the main drivers of tourists' destination choices (Amaro et al., 2016), which are a rich source of user-generated content (UGC). However, studies that look at actual online behavior are scarce. Given that tourists differ significantly in their social media utilization (Amaro et al., 2016) and as residents vary with respect to their attachment to a place (Young et al., 2007), it seems most likely that residents as place-brand ambassadors can be classified into different groups based on their social media behavioral patterns and UGC. Social media is often regarded as projecting perceived images of a place, though no place brand research has so far observed residents' actual social media usage, and has relied mostly on self-reported data (e.g. Stylidis et 
al., 2016; 2017). Further, although several studies have sought to examine stakeholders' engagement using social media data, stakeholders are not adequately determined according to their stake; i.e. their research samples were neither residents nor tourists, but "social media users" in a broad sense.

Places are becoming competitive with the progress of globalization, both to live in and to visit, and residents have increasingly been identified as important stakeholders in fostering tourism (e.g., Boley et al., 2014; Braun et al., 2013; Palmer et al., 2013; Strzelecka et al., 2017). Recent media reports have highlighted the tension between competing interests of residents set against tourists in Barcelona and Venice (Coldwell, 2017). For tourism to be sustainable, achieving the commitment of residents is pivotal; especially for small communities and medium-sized, non-capital cities around the world, whose economic viability is dependent on tourism. In this context, the influence of social media has also been discussed as a powerful tool to generate electronic Word-of-Mouth (eWoM), whereby non-residents can learn about a place directly from its residents (Arsal et al., 2010). Several themes can be identified within the existing body of research focusing on residents and tourism: i) examination of attitudes and perceptions of residents towards tourism (Boley et al., 2014; Nunkoo \& Gursoy, 2012; Nunkoo \& So, 2016; Strzelecka et al., 2017); ii) residents as part of the attractiveness or image of the destination, particularly with conflicting interests (Stylidis et al., 2016, 2017); and iii) residents as co-creators of the place brand (Arsal et al., 2010; Braun et al., 2013; Kavaratzis, 2004). Nonetheless, research aimed at better understanding the role of residents is still insufficient, particularly examining actual (as opposed to self-reported) behavior, but also in the context of small and medium-sized communities.

Therefore, there is a compelling need for a study exploring the residents' role as ambassadors in sustaining their communities by actively engaging in place marketing via the web. Consequently, this paper addresses the following research aims:

I. Identify the types of content that residents are engaging in, and what their intentions are when generating UGC about their place.

II. Develop a classification of residents based on their actual behavior online as place-brand ambassadors. 
In order to achieve these aims, the present research follows the precedent set by previous studies in the field (Mariani et al., 2017; Shakeela \& Weaver, 2012; Stylidis et al., 2015, 2016) and focuses on a unique destination-setting: Onomichi, a city located in the middle of Japan, along Setonaikai (Seto Inland Sea) in Hiroshima Prefecture.

\section{Theoretical bases for understanding the role of residents}

Stakeholder theory (Freeman \& McVea, 2001) points out the importance of acknowledging the variety of stakeholders, and is useful in understanding the distinct perception of place images among different stakeholders (Maheshwari et al., 2014). Stylidis et al. (2015) identify diverse place perceptions of different stakeholders, which may even conflict with each other (e.g. residents may have a negative attitude towards visitors). Stylidis et al. (2016) further explore the role of residents and show that destination-related attributes (e.g., scenery, accommodation) are predominantly used in studies assessing residents' perceptions as opposed to community-related attributes (e.g., job opportunities). Additionally, they introduce a holistic measurement framework comprising the dimensions of: i) Physical appearance, ii) Community services, iii) Social environment, and iv) Entertainment opportunities. These dimensions are plotted on two continua ranging from: a) destination to community, and b) functional to psychological.

Kavaratzis (2012) points to stakeholders' role as co-creators, highlighting the importance of stakeholder empowerment. Residents are an integral part of the place branding process, acting as place brand ambassadors, as well as citizens, and voters for political legitimization (Braun et al., 2013). Therefore, effective and sustainable place branding is only feasible with residents' meaningful participation. Out of these three roles, the ambassador role has received growing attention in the place branding context. Braun et al. (2013) explain the ambassador role based on Kavaratzis' City Image Communication Model (2004, see Figure 1), which identifies tertiary communication such as Word-of-Mouth (WoM) as a key outcome.

Zenker et al. (2017) indicate that as place brand complexity increases, more residents tend to act as place ambassadors through providing favorable WoM. Brand complexity is thereby correlated with residents' attitude and behavior toward places, such as satisfaction, identification, attachment, and WoM. Nunkoo and Ramkissoon (2012) as 
well as Nunkoo and So (2016) explain residents' support for tourism based on social exchange theory and identity theory, and propose that residents' place image and its influence on residents' attitudes and behavior toward tourism needs to be investigated. Stylidis et al. (2015) respond through linking residents' place image and support as shown in Figure 1, i.e., residents' place image positively influences the perception of tourism impact, which makes residents more supportive for the tourism industry. In addition to the previously discussed place image dimensions, Stylidis et al. (2017) add place attachment as a separate dimension that refers to the perception of a place, which affects residents' attitudes towards tourism.

Therefore, building on extant research, a more holistic perspective of place branding can be formed based on stakeholder theory, social exchange theory, and social identity theory (Figure 1). From this theoretical foundation, the present study moves forward towards a classification of residents' ambassadorial roles in the online context, given the broadening reach of online communication and the increasing influence of this on the travel and tourism industry.

Figure 1. Conceptualization of Residents' Ambassador Role in Place Branding. 
Kavaratzis (2004)

City Image Communication

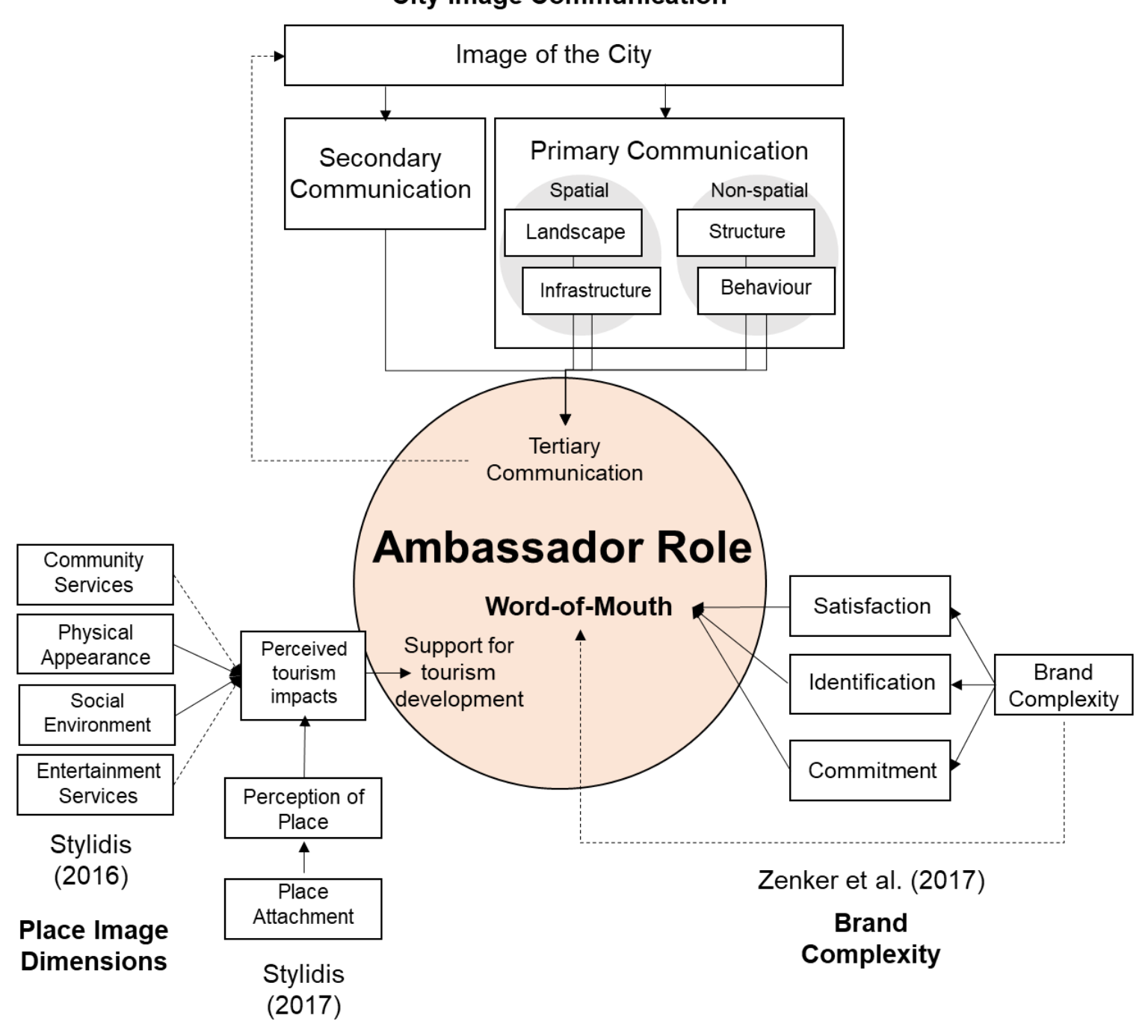

Place Attachment

\section{Residents' utilization of social media in tourism}

The utilization of social media by various groups of stakeholders to express their perceptions and views has received much attention in recent years due to the proliferation of social media platforms and the richness of their content (Smith et al., 2012). Social media platforms are typically a rich source of User Generated Content (UGC), including narrative texts (e.g. travel blogs, microblogs), visual (photos and videos) and audio segments (Munar, 2011). However, despite the importance and diversity of UGC and social media, studies linking them to tourism are still relatively rare (Zeng \& Gerritsen, 2014). 
Bonsón and Ratkai (2013) measure stakeholders' engagement on corporate Facebook accounts and derive three metrics from the data extracted from Facebook; namely popularity, commitment and virality. Further examination of official Facebook accounts of local authorities, such as city councils, shows that content type (e.g. environment, housing) and media type (e.g. video, text) affect the level of citizens' engagement on Facebook (Bonsón et al., 2015). In the journey-planning process, UGC is regarded as an important and more trustworthy source compared to DMO websites (Jacobsen \& Munar, 2012; Xiang \& Gretzel, 2010), which makes it a crucial asset in place-marketing efforts. Indeed, as Ketter and Avraham (2012) underscore, social media allows users to create, as well as engage with, place-marketing campaigns that were previously generated solely by DMOs. Studies have also highlighted differences in the motivations for individuals to generate UGC; for example, travelers share their experiences on social media for community-oriented motivations as well as self-oriented ones (Kang \& Schuett, 2013; Munar \& Jacobsen, 2014).

However, there is a dearth of studies that specifically focus on the use of social media by residents and their motivations for doing so in the context of place branding. Notable exceptions in this respect are Shakeela and Weaver's (2012) examination of residents' emotional reactions (online) in response to a YouTube video of a servicesabotage incident in Maldives, and Kirilenko and Stepchenkova's (2017) analysis of the Twitter activity of hosts versus guests in relation to the Sochi Olympics. Nonetheless, to the best of our knowledge, no previous work has adequately focused on the role and motivations of residents in promoting their 'place' online to visitors and tourists.

\subsection{Twitter usage and tourism}

Twitter is a popular microblogging platform where users can share short pieces of content in text, image, or video format to their followers (people who have indicated a preference to view another user's content or postings) and publicly, whilst also following other users and consuming their content output. Toubia and Stephen (2013) point out that posting content on Twitter, or tweeting, is not only a user's means of disseminating information or ideas, but also of attracting followers. Similarly, a user can also simply share another user's post as it is, which is known as a retweet. 
Twitter serves as a real-time engagement tool between tourists and other stakeholders, a repository of documented live experiences (e.g., tweets during a concert), and an effective platform for electronic word-of-mouth (eWoM) received from other users, who are not part of one's network of social connections (compared to Facebook for example) (Williams et al., 2015). The advantage of Twitter for tourism has been recently reemphasized by Salas-Olmedo et al. (2018) who point out that an individual's tweet (about a tourism destination for example) is instantly available for any internet user around the world (unless the tweet is private), but particularly also because it carries geolocation data that is available for analysis.

Importantly, whilst previous studies in the context of Twitter and tourism have provided valuable insights, focusing on individual users' content topics and characteristics (see: Kirilenko \& Stepchenkova, 2017; Williams et al., 2015), a classification of users as promulgators of eWoM has yet to be attempted to the best of our knowledge. Identifying and understanding distinct groups of social media users is vital for effective marketing strategies in the digital era in most business contexts, as previous studies have illustrated (see: Amaro et al., 2016; Müller et al., 2018).

\section{Importance of the Japanese context and the case of Onomichi}

Funck (2008) emphasizes that the aging population of Japan presents challenges in the supply side of tourism, though most attention in the tourism literature seems to be focused on the demand (or consumption) perspective. In Japan, rural depopulation is recognized as a serious problem all over the country, and the revitalization of regional economies has become vastly more important. Though Japan has the $10^{\text {th }}$ largest population in the world, the country's population has been decreasing and has become concentrated in major metropolitan areas. For instance, $51 \%$ of the total population of Japan lives in only three major metropolitan areas, including the Greater Tokyo Area, whilst other areas have experienced population decline. Specifically, small villages in danger of extinction are called Genkai Shūraku (marginal settlements); 190 settlements (including 27 Tsunami-affected areas) have already vanished since 2011, and 570 settlements are predicted to disappear by 2025 (Ministry of Land, Infrastructure, Transport \& Tourism, 2016). For this reason, Chiiki Saisei (revitalization of a region) has long been the center of concern in Japan (Rausch, 2015), but most of these places struggle to attract more residents as well as tourists. Residents play a 
variety of roles in attracting tourists as an authentic source of information, especially as social media provides increasing connectivity between residents and tourists (Arsal et al., 2010; Braun et al., 2013; Xiang \& Gretzel, 2010). Hence, the role of residents in attracting tourists in the Japanese context is particularly pivotal.

Onomichi is the 200th largest city among the 1741 cities in Japan, located in an area covering $285 \mathrm{~km}^{2}$ that comprises the mainland and six neighboring islands. The local economy is mainly based on shipbuilding, food processing, orcharding, and the chemical and metalworks industries. Although the city has experienced economic decline and the population dropped from 145,202 in 2010 to 138,626 in 2015 (Ministry of Internal Affairs \& Communication, 2015), it is one of the successful cases of revitalization. The scenery of the old city and the landscape also attract many authors and filmmakers as settings for films, novels, dramas, Anime (Japanese animation) and Mangas (Japanese comics). Furthermore, new attractions are created to revitalize the city, using unique aspects of the city including Onomichi's famous cats, narrow streets with slopes and old houses. For example, a cat-eyed online map called Cats Street View was introduced, which allows potential visitors to roam around the city form a cat's perspective (Horton, 2015). The Akiya-Saisei Project is another interesting example, which targeted new residents through the renovation of abandoned homes. This project has also attracted national and international tourists because several new residents founded tourism businesses using these properties (Akiya Saisei, 2017).

From a broader perspective, Onomichi's case can be compared to that of several other locations worldwide that have undergone socio-economic changes affecting tourism, and have staged a resurgence through cultural revitalization. However, the role and place of residents in such cases of socio-economic resurgence is subject of debate and remains to be better understood; examples of such places include Udine and Bologna in Italy (Kresl \& letri, 2010), and Britain's seaside towns such as Margate (BBC, 2015; Ward, 2018). By examining a Japanese city, our study therefore addresses the need for further place branding research in Japan and the Asia-Pacific region, but also provides insights for broader regional development goals across the globe.

\section{Methodology}


This study employs a broadly post-positivist methodology in that the researchers seek to uncover significant patterns within qualitative data, akin to that of phenomenographic research in tourism focusing on categorization or clusterdevelopment (see: Govers et al., 2007; Ryan, 2000). Accordingly, under the overarching framework of discourse analysis, this study adopts the content analysis method to analyze (qualitative) data, in line with earlier studies in tourism research (e.g., Govers et al., 2007; Költringer \& Dickinger, 2015). Content analysis is a technique for analyzing communication patterns by interpreting communication media such as texts or photos through quantitative and qualitative elements (Hannam \& Knox, 2005). The method originates from communication studies, which focus on the frequency of particular keywords (Schreier, 2012), that are coded and categorized so that qualitative data can be analyzed quantitatively. Subsequently, content analysis has developed to include a stronger focus on qualitative-content analysis (thematic coding), which examines the context of textual data, rather than mere word-frequency analysis. Thus, whilst retaining benefits of a (post)positivistic approach, the current study attempts to uncover meanings associated with the data, appreciating the context within which they are created.

\subsection{Data collection and usage}

Twitter was selected as a source because it is more accessible for retrieving text, photographs and profile data in contrast to various other social media platforms. Further, Twitter is the second most popular social media platform in Japan (Wong, 2017); some of its functions such as retweets and hyperlinks make Twitter a unique tool (Rogers, 2013), which is suitable for measuring the engagement levels of stakeholders. Twitter data used in this study were in the public domain, and all traces of identifying particulars were removed before the analysis was conducted.

When attempting to extract residents from Twitter, we adopted a technique focusing on users' locations, profiles, and usernames, which resulted in 500 Twitter accounts based in Onomichi, out of which 124 were individual residents' accounts. A total of 567,328 tweets by Onomichi residents, selected based on location data from profiles, were retrieved using the NVivo-NCapture tool. Of these, 8,038 tweets were identified and coded using the time limit function as the sample tweets of the designated period for analysis. These, originated from 44 individual residents' accounts, representing 
roughly $10 \%$ of the estimated Twitter users in the focal destination, Onomichi. An overview of the sampled accounts and profile details are provided in Appendix A.

However, it is unrealistic to expect residents to consistently generate a high volume of tweets relating to a place throughout the year. Furthermore, an initial analysis of the Twitter activity of the residents revealed that tweets about Onomichi were mostly concentrated around a main holiday period (i.e., tourist season). Consequently, the data analysis was focused on tweets from the $21^{\text {st }}$ April 2017 to the $21^{\text {st }}$ May 2017 , as this period includes the Golden Week, which is the longest holiday season of the year for most of Japan. Also, one of the biggest festivals in Onomichi, called Minato Matsuri (port festival), was held during this period, from the $22^{\text {nd }}$ to the $23^{\text {rd }}$ April, in addition to major events such as the closing ceremony of the Onomichi station and the broadcast of the famous TV program called "BlaTamori" featuring the City of Onomichi. For these reasons, and based on historic Twitter activity, authors identified this period as the one with the highest intensity of Twitter usage by residents. In this respect, our approach closely follows that of previous studies in tourism, including Williams et al. (2015) study of Twitter data during the Bournemouth Air Show in the UK, and Kirilenko and Stepchenkova's (2017) analysis of tweets about the Sochi Olympic Games in Russia.

Using the captured tweets' content, we attempted to ascertain clusters of users, who were similar in the Twitter usage to others within the same cluster, and different to those outside that cluster (i.e., members of other clusters). We used Nvivo for this purpose, whereby clustering was done based on coding similarity/dissimilarity (see: Bazeley \& Jackson, 2013). To allow for a comparison in terms of tweet volume and intensity, the analysis also considers three DMOs and three local media organizations, which would help clarify the role played by residents.

\subsection{Data coding}

Whilst some researchers emphasize the importance of category and a priori design that defines the rule prior to the observation when undertaking content analysis (e.g., Stepchenkova et al., 2009), this is more applicable when conducting a quantitative analysis. Since a coding strategy is not usually designed solely based on a data-driven approach (Schreier, 2012), the coding categories for the current study were created by combining both data-driven and theory-driven approaches. 
Coding strategies of three previous studies were consulted for building the categories used in this study. First, Dickinger and Költringer (2011) compared the text content of DMOs' official sites and UGC (travel blogs) in five cities. They developed 12 main categories, including: sights, transportation and history (Költringer \& Dickinger, 2015). Second, Sevin (2013) investigates DMO's tweets and conducts two types of coding; one based on type of Twitter activity (e.g., information sharing, dialogue, and forwarding), and the other based on type of place image, including business, culinary aspects and events. Lastly, Okazaki et al. (2015) explore customer engagement in social media using social capital theory. Tweets about IKEA are investigated and categorized into three forms of eWoM, including objective (fact-based) statement, subjective (positive or negative) statement, and knowledge sharing; these act as a driver of social capital. Furthermore, Okazaki et al. (2015) identify "prosumers", i.e., those, who actively engage in value co-creation. By combining and adapting the coding from these studies, we subsequently developed seven main coding categories and 25 sub-categories, which were verified by three independent academic reviewers; the cross-comparisons allowed authors to test the data interpretation. Further details of these categories are provided in Appendix B.

To identify and consistently code Onomichi related tweets (ORT), an Onomasticon (a dictionary of proper names) of Onomichi was created. The Onomasticon was composed in line with 25 topic categories (see Appendix A). Most categories were predesigned referring to the categories in the studies of Dickinger and Költringer (2011), Stylidis et al. (2015, 2016), and Zenker et al. (2017), and adjusted after test coding. Each topic-related term was searched from the official websites of the Onomichi city council and the Onomichi tourist association, with a total of 1,401 names being selected. Each topic term on the Onomasticon was searched using the Nvivo search query function, and the received tweets were coded into each category names. After repeating the same process 25 times, 1,551 tweets out of 8,038 were coded as ORT, which were subjected to further analysis to identify topic categories and tweet intentions.

\section{Data analysis and findings}

6.1 Descriptive analysis of the sample 
The descriptive analysis (Table 1) shows that residents tend to tweet more often $(12,894$ tweets on average since the Twitter account was first registered) than DMOs (3,864 tweets on average) and local media (4,517 tweets on average). This suggests that residents tweet more casually (based on interests, hobbies, conversations etc.), whilst DMOs and local media use Twitter more deliberately in that it is with a specific purpose to present a particular image (marketing, publicity etc.). DMOs have about ten times more followers than the average resident, although the number beingfollowed by them is more comparable. Since local media repeatedly posted the same tweets, which were largely irrelevant to this study's purpose, it was deemed further analysis of local media output would not be of value.

Table 1. Demographics of Study Sample.

\begin{tabular}{lrrr}
\hline Source & Resident & DMO & Local Media \\
\hline Accounts & 44 & 3 & 3 \\
All Tweets (since account's registration) & 567,328 & 11,591 & 13,552 \\
Avg. Tweets (Tweets / Account) & 12,894 & 3,864 & 4,517 \\
Avg. Following (Following / Account) & 480 & 647 & 796 \\
Avg. Followers (Followers / Account) & 685 & 5,078 & 876 \\
\hline Tweets during sampling period* & 8,038 & 53 & 243 \\
\hline
\end{tabular}

Note. Data retrieved from Twitter. *Sampling period= from 21/04/2017 to 21/05/2017

A word frequency test was conducted; the results of which are summarized in Figure 2. "Onomichi (尾道) " was the most frequently used term with 1,634 times in 8,038 tweets (1.29 weighed percentage), but only the second most frequent word for DMOs with 43 counts ( 5.30 weighed percentage) in 53 tweets (see Appendix $C$ for a complete illustration of frequently used words by DMOs). Moreover, residents mentioned "Onomichi" three times as often compared to the second most frequent term, "today ( 今日)" (570 counts). Several area names were also part of the top 30, including "Hiroshima" (Prefecture, ranked in 7th), "Fukuyama" (neighbour city, 24th), "Innoshima" (one of the Onomichi Islands, 25th). This shows that residents tweet about the Onomichi area quite frequently.

Figure 2. Word Frequency Test of Residents' Tweets. 


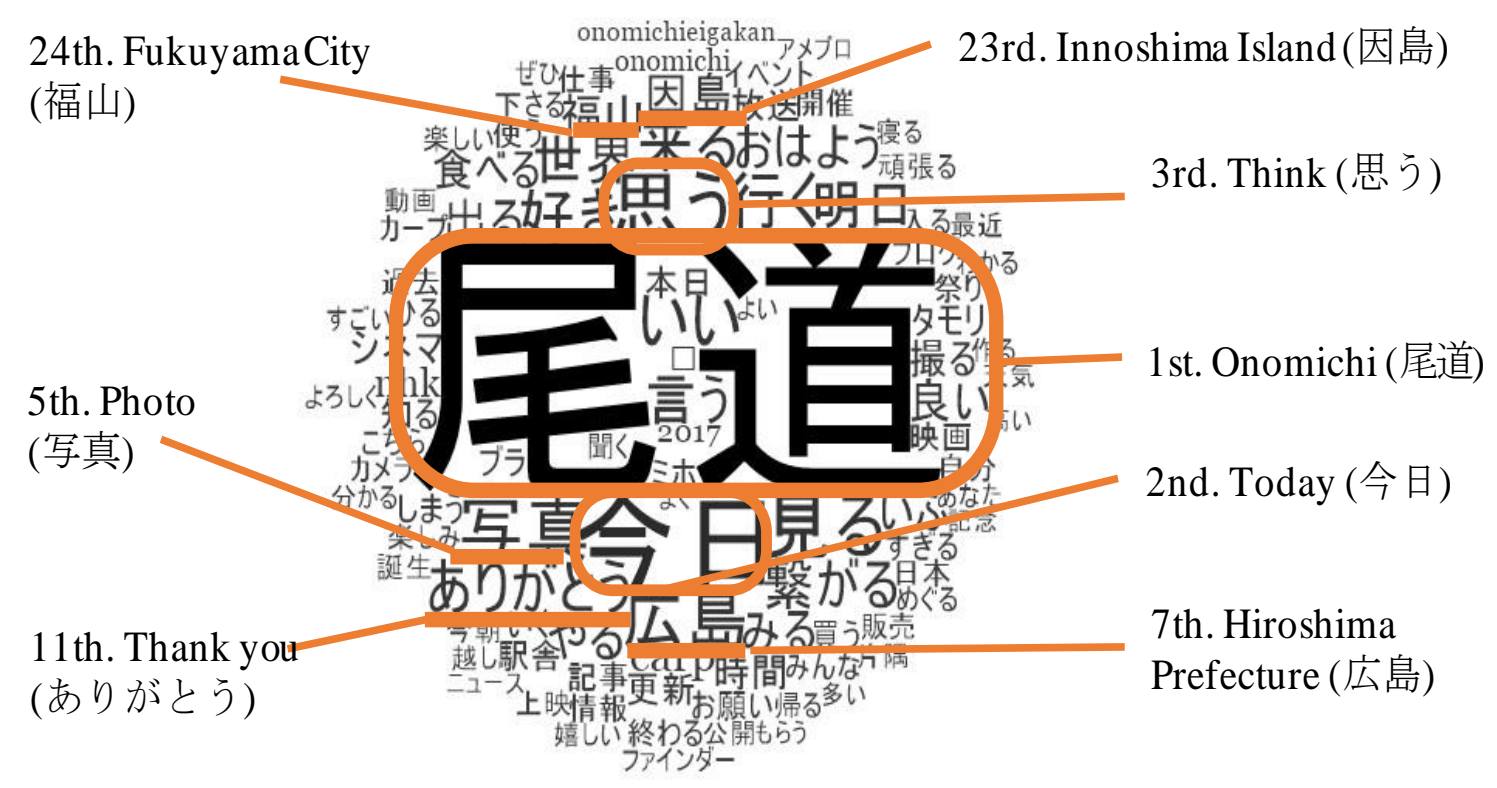

Note. Examining 8,038 posts tweeted by Onomichi residents from 21 April to 21 May 2017.

\subsection{Topic categories}

The contents of the tweets, including hashtags, were coded according to the seven main categories and 25 sub-categories (specified in Appendix B). Table 2 shows that most of the ORTs contain place names (90.20\%), particularly Onomichi (73.16\%). This is due to most residents actively promoting events or specific attractions in Onomichi, as well as sharing their impressions of specific places. The second most common category is related to occasional events (24.73\%), with five significant events identified for the time-period examined. Tweets related to physical appearance (17.23\%) and entertainment services (12.17\%) also appeared relatively often, whilst community services (2.69\%) and social environment (1.15\%) were rarely discussed.

The most covered topic, outside of the place-name, was the weather $(9.48 \%)$; however, this was primarily due to a limited number of people repeatedly tweeting about daily weather or posting photos of the sky. The second most discussed topic was about cats $(8.71 \%)$ since there were several cat-related events taking place in the Onomichi area. For example, the unique cat tote bags drew considerable attention, which were sold out within a day. People retweeted the resale information and expressed their expectations. Further, scenes of the festivals and people wearing catcostumes were reported in the tweets. In respect of the range of coverage, a TV program called "BlaTamori" featuring Onomichi drew excitement and was widely shared by some of the residents (40\%). However, it is noticeable that only a few tweets 
refer to the "Minato Matsuri" (port festival), which is one of the largest festivals in Onomichi. Most of the occasional events on the other hand, were discussed often, and by many more residents. We speculate that this is because Minato Matsuri is already very well-known and therefore, is take-for-granted to be a major event during this period, whereas some of the occasional and small events need to be heavily promoted to be successful.

Table 2. Coding Results of Residents' ORTs

\begin{tabular}{|c|c|c|c|c|c|}
\hline \multicolumn{2}{|c|}{ Topic Category } & \# Accounts & $\%$ & \# Tweets & $\%$ \\
\hline$\overline{\text { ORTs }}$ & Onomichi Related Tweets & 44 & & 1,561 & \\
\hline \multicolumn{4}{|c|}{ Place Name } & 1,408 & $90.20 \%$ \\
\hline A1 & Onomichi & 36 & $2.31 \%$ & 1,142 & $73.16 \%$ \\
\hline A2 & Island names & 16 & $1.02 \%$ & 195 & $12.49 \%$ \\
\hline A3 & Area name & 13 & $0.83 \%$ & 71 & $4.55 \%$ \\
\hline \multicolumn{4}{|c|}{ Physical Appearance } & 269 & $17.23 \%$ \\
\hline P1 & Scenery & 13 & $0.83 \%$ & 67 & $4.29 \%$ \\
\hline P2 & Architecture & 10 & $0.64 \%$ & 54 & $3.46 \%$ \\
\hline P3 & Weather & 07 & $0.45 \%$ & 148 & $9.48 \%$ \\
\hline \multicolumn{4}{|c|}{ Community Services } & 42 & $2.69 \%$ \\
\hline $\mathrm{C} 1$ & Local services & 05 & $0.32 \%$ & 11 & $0.70 \%$ \\
\hline $\mathrm{C} 2$ & School & 07 & $0.45 \%$ & 27 & $1.73 \%$ \\
\hline $\mathrm{C} 3$ & Business & 03 & $0.19 \%$ & 04 & $0.26 \%$ \\
\hline \multicolumn{4}{|c|}{ Entertainment Services } & 190 & $12.17 \%$ \\
\hline E1 & Gourmet & 11 & $0.70 \%$ & 34 & $2.18 \%$ \\
\hline E2 & Lifestyle & 12 & $0.77 \%$ & 16 & $1.02 \%$ \\
\hline E3 & Culture & 14 & $0.90 \%$ & 75 & $4.80 \%$ \\
\hline E4 & Event & 13 & $0.83 \%$ & 59 & $3.78 \%$ \\
\hline E5 & Shopping & 03 & $0.19 \%$ & 06 & $0.38 \%$ \\
\hline \multicolumn{4}{|c|}{ Social Environment } & 18 & $1.15 \%$ \\
\hline $\mathrm{S} 1$ & Community group & 00 & $0.00 \%$ & - & $0.00 \%$ \\
\hline S2 & Local media & 04 & $0.26 \%$ & 07 & $0.45 \%$ \\
\hline S3 & Celebrity & 05 & $0.32 \%$ & 11 & $0.70 \%$ \\
\hline \multicolumn{4}{|c|}{ Tourism } & 81 & $5.19 \%$ \\
\hline $\mathrm{T} 1$ & Specialty & 08 & $0.51 \%$ & 31 & $1.99 \%$ \\
\hline $\mathrm{T} 2$ & Tourism & 08 & $0.51 \%$ & 10 & $0.64 \%$ \\
\hline $\mathrm{T} 3$ & DMOs & 10 & $0.64 \%$ & 40 & $2.56 \%$ \\
\hline \multicolumn{4}{|c|}{ Special Event during Period } & 386 & $24.73 \%$ \\
\hline $\mathrm{O} 1$ & Minato Matsuri & 08 & $0.51 \%$ & 34 & $2.18 \%$ \\
\hline $\mathrm{O} 2$ & TV broadcast & 18 & $1.15 \%$ & 91 & $5.83 \%$ \\
\hline $\mathrm{O} 3$ & Station closing & 16 & $1.02 \%$ & 72 & $4.61 \%$ \\
\hline $\mathrm{O} 4$ & Golden Week & 15 & $0.96 \%$ & 53 & $3.40 \%$ \\
\hline O5 & Cat Festival & 14 & $0.90 \%$ & 136 & $8.71 \%$ \\
\hline
\end{tabular}




\subsection{Intention behind the tweets}

To identify the intentions for their tweets, we closely examined how residents expressed Onomichi in their posts, including hashtags, and followed a manual coding process for classifying them. The coding categories were built according to the Codebook for Nature of Conversation (Sevin, 2013) and Dialogue Acts (Okazaki et al., 2015). The categories were redesigned to correspond with residents' tweets because existing research focuses on either marketers' promotional tweets or interaction between a brand and brand followers.

The new categories are described by two axes, which emerged in the process of test coding. The first axis shows whether a tweet contains sentimental (subjective) or nonsentimental elements (objective). The second axis describes if a tweet directly (place, shop, or event information) or indirectly (ongoing or past report of events) impacts on readers' immediate actions. Based on this, four main code categories were developed; namely: Advertisement, Suggestion, Description, and Impression (see Figure 3). In addition, Art and Play (portraying Onomichi as a stage of art or center of games), Q\&A (asking and answering questions), and Daily Chat (routine dialogue such as greetings, weather, baseball and cats) were also identified as prominent themes. Codes with negative sentiments were categorized separately.

Table 3 gives an overview of residents' tweet intentions by identifying the number of residents and tweets; examples of typical tweets per types of intentions for tweeting are given in Appendix D. Advertisement was the tweet intention that was observed most, covered by a wide range of residents (54.55\%). Most of the advertising tweets were retweets, with DMOs and museums as the original advertisers, except for bloggers, who advertised their blogs featuring Onomichi. 'Art and Play' was the second largest category, although a limited number of residents repeatedly posted stylized tweets with hashtags. Residents portrayed Onomichi in various ways, such as photogenic subjects, themes for Haiku (Japanese poem), and game stages of location-based augmented reality games. The strongest endorsements, both, towards events and places, appeared in the Q\&A category. Furthermore, no apparent negative feelings were detected, although a few tweets could be interpreted as slightly negative; 26 tweets from 11 residents, which were generally not negative against Onomichi, but rather self-deprecating whilst referring to countryside life or tourism. 
Figure 3. Conceptual Map of Residents' Tweet Intentions.

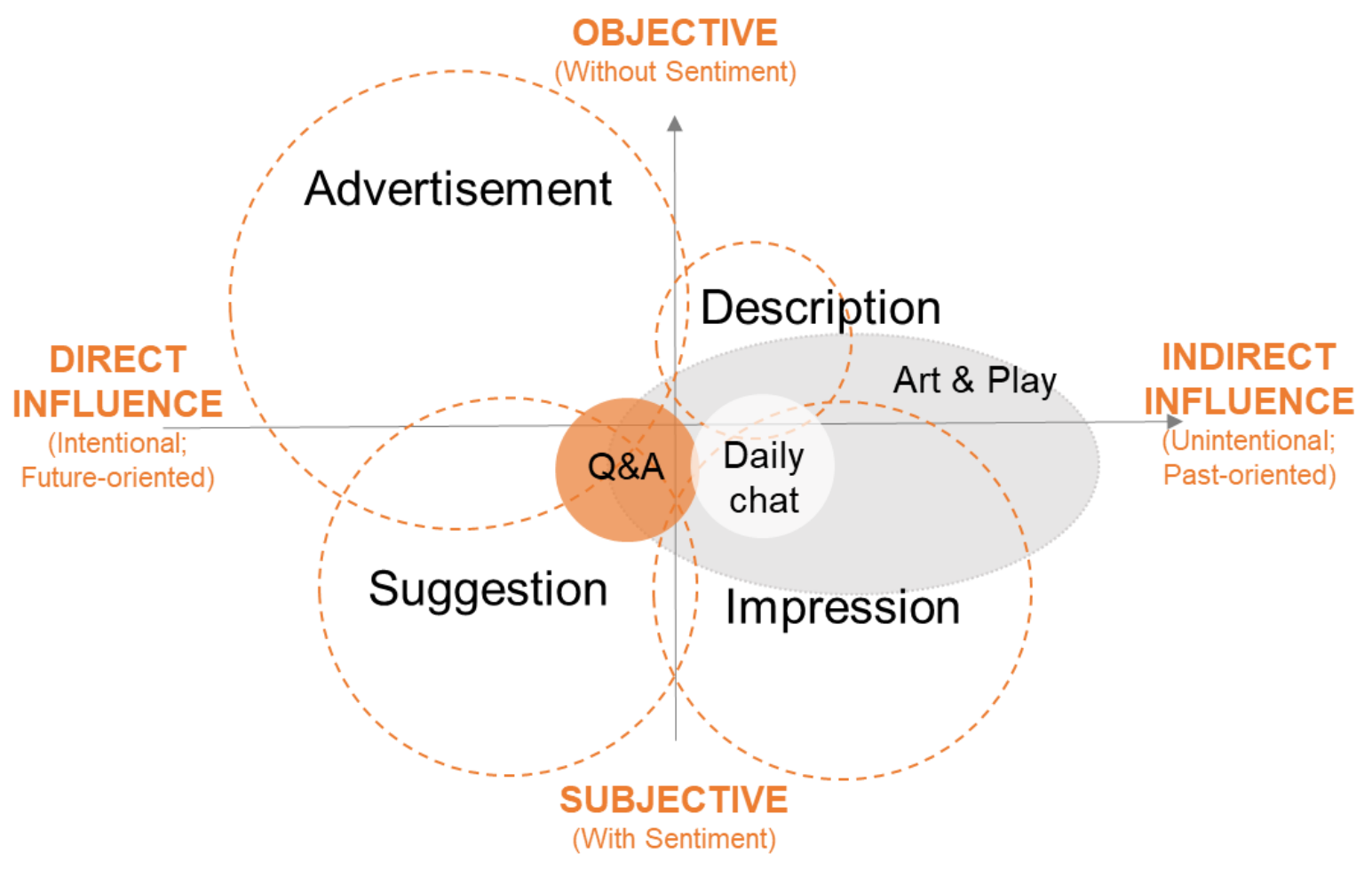

As for the tweets from the DMOs, the main categories observed were Advertisements, Suggestions, and Scenery. Advertisements were most prominent and centered on events including the Minato festival, station building-closing ceremony, and "bochu giku" (Dalmatian chrysanthemum flowering event) as well as promotions such as the "Calico cat tote bag sale" and "Onomichi 365" (recently opened free resting and BBQ area in Neco no Hosomichi). This category of activity by DMOs was comparable to the residents' activity under the Advertisements category, but differed in that the DMOs understandably seem to take a broader perspective towards public benefit in some respects (e.g. "Onomichi 365"). In terms of Suggestions however, DMOs tweets also focused on the TV program "Bla Tamori". Similarly, regarding Scenery, DMOs posted photographs of beautiful scenery, such as seasonal flowers, myriad stars in the night sky, and panoramic views from a mountain. Overall, DMO activity was rather limited in range in addition to being more purpose-oriented (advertise festival or other events, show beautiful scenery to promote tourism).

Table 3. Coding Results of Residents' Tweet Intentions. 


\begin{tabular}{|c|c|c|c|c|c|}
\hline Tweet intention & $\begin{array}{l}\text { No of } \\
\text { references }\end{array}$ & $\begin{array}{l}\% \text { within } \\
\text { total No } \\
\text { of tweets }\end{array}$ & $\begin{array}{l}\text { Sources } \\
\text { (No of } \\
\text { residents) }\end{array}$ & $\begin{array}{l}\% \text { within } \\
\text { total No of } \\
\text { sources }\end{array}$ & Examples \\
\hline Daily chat & 99 & $6.34 \%$ & 21 & $47.73 \%$ & $\begin{array}{l}\text { Chit-chat about weather, } \\
\text { cats, baseball, and trains, } \\
\text { and greetings }\end{array}$ \\
\hline Advertisement & 293 & $18.77 \%$ & 24 & $54.55 \%$ & $\begin{array}{l}\text { Future event information, } \\
\text { promoting own (future } \\
\text { events, shops, blogs etc.) }\end{array}$ \\
\hline Suggestion & 212 & $13.58 \%$ & 21 & $47.73 \%$ & $\begin{array}{c}\text { Recommending others } \\
\text { (future events, shops, area } \\
\text { etc) }\end{array}$ \\
\hline Description & 84 & $5.38 \%$ & 12 & $27.27 \%$ & $\begin{array}{l}\text { Report (past or ongoing } \\
\text { events, news, scenery) } \\
\text { without sentiment }\end{array}$ \\
\hline Impression & 238 & $15.25 \%$ & 23 & $52.27 \%$ & $\begin{array}{l}\text { Report (past or ongoing } \\
\text { events, news, scenery) with } \\
\text { sentiment, opinion }\end{array}$ \\
\hline Art \& Play & 276 & $17.68 \%$ & 9 & $20.45 \%$ & $\begin{array}{c}\text { Photo (sky, morning), poem } \\
\text { (Haiku), game (Ingress, } \\
\text { PokemonGo) }\end{array}$ \\
\hline Conversation & 95 & $6.09 \%$ & 16 & $36.36 \%$ & $\begin{array}{c}\text { Answering someone's } \\
\text { question (cannot presume } \\
\text { proper context) }\end{array}$ \\
\hline $\begin{array}{l}\text { Opinions/Need- } \\
\text { expressions }\end{array}$ & 26 & $1.67 \%$ & 11 & $25.00 \%$ & $\begin{array}{l}\text { E.g. "More parking needs } \\
\text { to be built in Onomichi" }\end{array}$ \\
\hline Other & 264 & $16.91 \%$ & 15 & $34.09 \%$ & $\begin{array}{l}\text { Not relevant; just } \\
\text { hashtagging }\end{array}$ \\
\hline TOTAL & 1,561 & $100.00 \%$ & 44 & $100.00 \%$ & \\
\hline
\end{tabular}

Sampling period 21/04/2017 to 21/05/2017.

\subsection{Classifying ambassadorial roles}

Focusing on the relationships between different aspects of residents' Twitter usage, we conducted several correlation analyses. Onomichi related tweets (ORTs) were highly correlated to total number of tweets during the period of analysis (the main holiday period or tourist season) $(p<0.01, r=0.677)$, but not to the total number of tweets overall ( $p>0.05, r=0.022)$. This indicates that online place ambassadors' Twitter activity (in promotion of their 'place') is more concentrated on main holiday/tourism periods. Although they do not have more followers in general ( $p>0.05, r=0.022)$, they are likely to have more followers from Onomichi $(p<0.05, r=0.318)$, and to be following others more $(p<0.01, r=0.488)$, which is indicative of good local connectivity. 
Tweets were also analyzed by focusing on the mention (@) function and retweet (RT) option, which allows for reposting of a tweet by others to share information. The results show that 33 residents retweeted with $31.10 \%$ coverage (2,500 tweets) of all 8,038 tweets during the period, and 37 users mentioned other people in 2,035 tweets (25.32\%). The usage of retweet and mention varied broadly among individuals. The most frequent user of RT used $718 \mathrm{RT}$ in 861 tweets; on the other hand, 11 people never shared content using "RT".

The topics of tweets varied significantly between individuals; by combining the topics with the Twitter usage patterns described above and tweet intentions (section 5.3), four distinct categories of ambassadorial roles could be identified as follows:

- Contributor: Contributors intentionally and actively tweeted and retweeted everything about Onomichi. Most common features of their tweets were Suggestion, Impression, and Q\&A themes. Some of them even declared that their account would mainly tweet about Onomichi, including Onomichi blogger. Their accounts were followed by other Onomichi residents, and their ORT were retweeted by them.

- Photographer: Photographers frequently posted series of photos, mentioning that these were taken in Onomichi. Although their intention was not advertising Onomichi but sharing their photos, the image of Onomichi could be inevitably spread through their tweets.

- Hobbyist: Hobbyists usually tweeted about their hobbies, including trains, Anime and cats. These hobbies were often related to Onomichi, and they actively tweeted about it and exchanged comments with hobby community members.

- Retweeter: Retweeters' regular tweet styles and topics differed, and were not particularly related to Onomichi. However, they often retweeted about significant events, such as festivals.

An illustrated summary of the ambassadorial roles is given in Figure 4, and further descriptive details are presented in Table 4.

Figure 4. Residents' Ambassadorial Role Types. 


\section{CONTRIBUTOR}

- ONOMICHI Representative

Tweet everything about Onomich

\section{PHOTOGRAPHER}

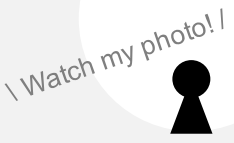

Express Onomichi

by photo, blog, poem etc.

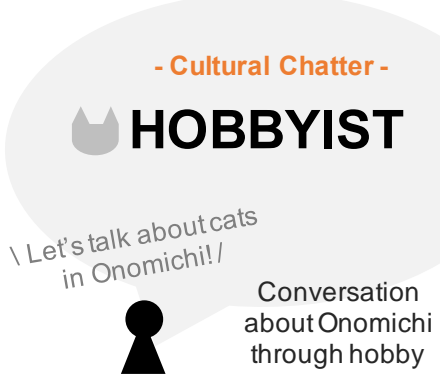

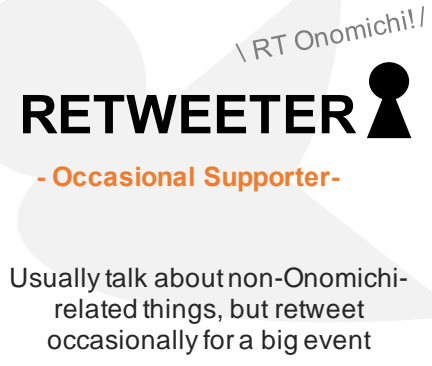

Table 4. Descriptive profile of ambassadorial role types

\begin{tabular}{lllllll}
\hline Role Type & $\begin{array}{l}\text { Avg. } \\
\text { tweets }\end{array}$ & $\begin{array}{l}\text { Avg. } \\
\text { retweets }\end{array}$ & $\begin{array}{l}\text { Avg. } \\
\text { followers }\end{array}$ & $\begin{array}{l}\text { Avg. } \\
\text { following }\end{array}$ & $\begin{array}{l}\text { Avg. } \\
\text { likes }\end{array}$ & $\begin{array}{l}\text { Avg. } \\
\text { mentions }\end{array}$ \\
\hline Contributor & 100.69 & 17.54 & 1115.46 & 473.38 & 2628.92 & 23.08 \\
Photographer & 204.63 & 11.13 & 196.13 & 232.50 & 793.00 & 24.75 \\
Hobbyist & 90.33 & 12.67 & 503.17 & 360.00 & 2208.50 & 22.83 \\
Retweeter & 267.65 & 123.94 & 649.59 & 644.94 & 10987.18 & 82.35 \\
\hline
\end{tabular}

\section{Discussion and theoretical implications}

This research explores residents' role as place-brand ambassadors via UGC that relates to their city of residence. Whilst previous studies have explored residents' declared intention to share WoM (e.g., Stylidis et al., 2015), the current study analyzes contents of actual tweets of the residents of Onomichi. The findings support that residents can intrinsically act as place ambassadors (Braun et al., 2013), adding credence to extant tourism literature on residents' support (e.g. Stylidis et al., 2016, 2017) and WoM (e.g. Zenker et al., 2017). Uncovering and mapping the different 
intentions of residents acting as online place-brand ambassadors, the present study also develops a specific categorization of residents, who recommend a place and support tourism through frequently tweeting about the region. Combining the findings with insights from extant literature, the authors propose a framework for understanding residents' role as place-brand ambassadors. As shown in Figure 5, the proposed framework summarizes the complexity of residents' ambassadorial role.

Figure 5. Framework for Understanding Residents' Place Ambassador Role.

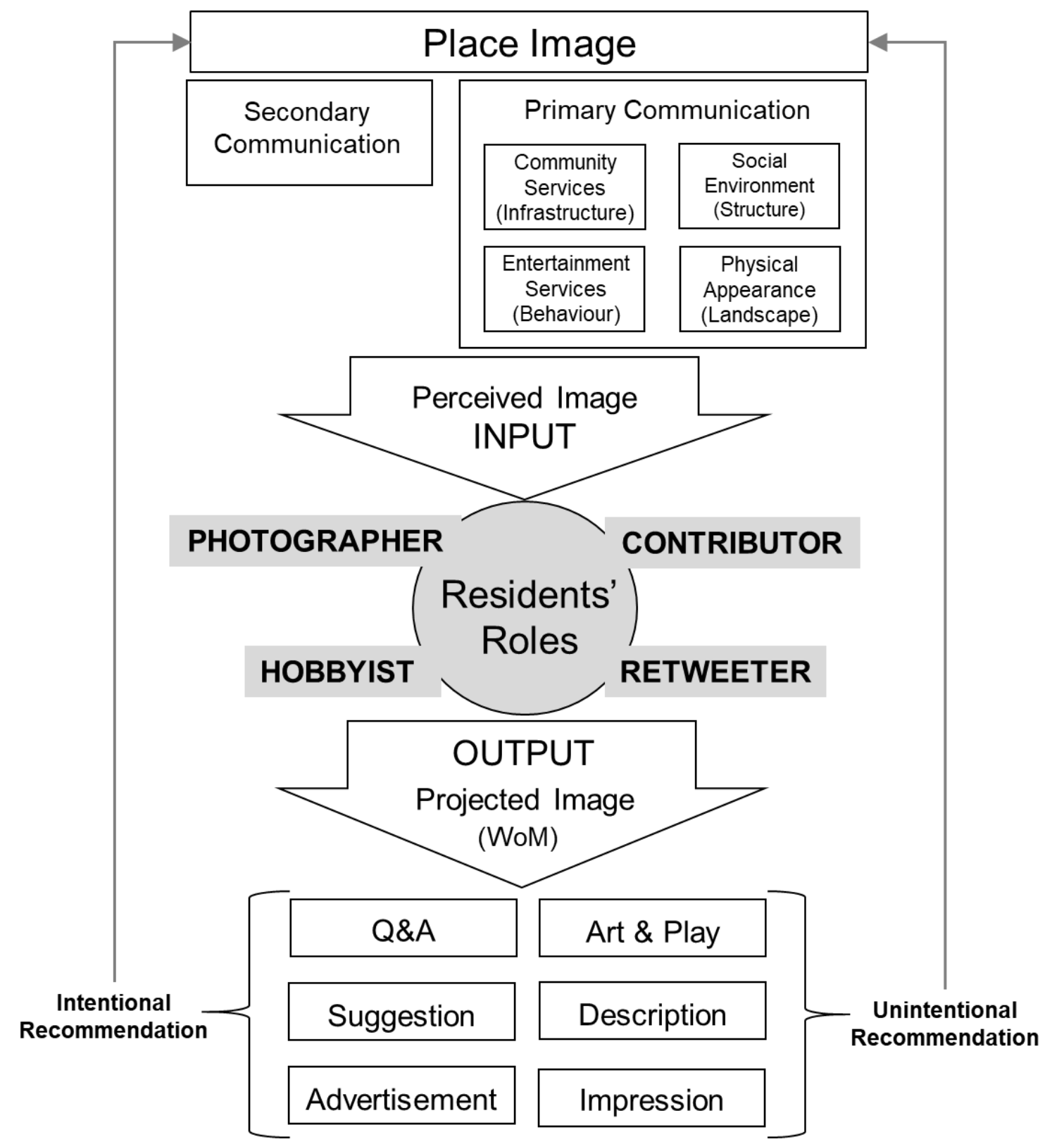

Whilst Stylidis et al. (2016) indicate that two image factors, namely physical appearance and social environment, influence residents' level of support, the present study shows that physical appearance, entertainment service and occasional events 
often appear as tweet topics, but references to the social environment were rarely observed. This finding could be explained by differences between perceived images (input) and projected images (output), bearing in mind also that the context of this study is different from that of Stylidis et al. (2016).

Closer examination of residents' tweets revealed two broad categories: general topics that attracted a wide audience, and specialized topics that a limited number of people tweeted repeatedly. The former is specifically seen in relation to occasional events such as the TV program and the station-closing ceremony. The latter covered a broad range of topics from Anime to music, within which most of the cultural hobbies were observed. From Zenker et al.'s (2017) brand complexity perspective, a diverse range of place brand variables can culminate in increased WoM. Therefore, as residents develop an image of a place over time, various cultural scenes, events and opportunities stimulate residents' eWoM through their tweets.

Our framework also integrates residents' roles and their tweet intentions. First, residents' tweet intentions were classified into eight categories. Most of these corroborated the categories proposed in earlier works, including question and answer, suggestion, dialogue (Sevin, 2013), sharing, information, and opinion (Okazaki et al., 2015). However, competition (Sevin, 2013), which calls for participation in promotional campaigns, was not found as it is peculiar to marketers. On the other hand, 'Art and Play' was a newly-elicited theme, unique to residents. This was further divided into three to represent residents' behavior more precisely; information propagation, Onomichi representative and advocating retweet. All these features could distinguish citizens from marketers, as well as giving a hint of understanding their motivations as to why they tweet about a city.

For residents tweeting for 'Art and Play' purposes, who were denoted as being a part of the Photographer category, there is high involvement and cost, since taking pictures and creating poems are skilled activities. Nevertheless, the benefits of displaying their work and getting reactions would be worth the cost to them, though each reward differs depending on individuals. For example, one of the residents who mainly posted 'Art and Play' type tweets constantly gained over 300 likes on each tweet. In contrast the Retweeter category is low involvement and low cost. The benefits for them might be an in-group feeling that provides a sense of belonging to the Onomichi community, 
which contributes to their self-esteem and identity as to who they are, as explained by Social Identity Theory (Tajfel \& Turner, 1979). Similarly, the Hobbyist group is probably also based on the benefits of forming stronger in-group feelings, as well as the benefits of belonging to a community of practice (see: McLeay et al., 2012). In this respect, Social Exchange Theory (Thibaut \& Kelley, 1959) is also relevant here in understanding the motivations of residents in acting as online place-brand ambassadors.

The Contributor group may receive a sense of belonging and respect in the community by showing off their knowledge about Onomichi. Adding to that, their attachment to Onomichi seems stronger, which drove them to intentionally and actively introduce Onomichi to the outside world, in comparison to the other three groups that were unintentionally involved in supportive behavior. The Contributor group's writing style reflects this, as they were often using phrases including "Please see/come/go" and "my city"; an example can be seen in the "Onomichi representative" type of suggestion tweets (see Appendix B). In sum, in-group feelings (Social Identity Theory), rewards (Social Exchange Theory), and place attachment affect residents to varying degrees and motivate their intentional or unintentional behaviors as online place-brand ambassadors.

Finally, negative tweets were rarely observed, probably because only residents with a positive image of tourism tweeted about the place, as previous research reveals that there is a correlation between residents' positive view of tourism and their level of support (Nunkoo \& Ramkisson, 2012; Stylidis al., 2015). Conversely, once the costs of tourism, such as traffic congestions and public disorder are factored in, residents' support might wane, and might ultimately provoke "tourism-phobia" as recently seen in some parts of Europe (Coldwell, 2017).

\section{Theoretical implications}

Our study adds to a growing body of literature, highlighting the importance of stakeholder involvement in the effectiveness and long-term sustainability of tourism and place-branding initiatives (e.g. Klijn et al., 2012; Zenker \& Beckmann, 2013). The nature of residents' contribution is entirely different from that of DMOs (which only exist to promote a place); the image generated by residents can be seen as organic as opposed to the paid (or inorganic) nature of place marketing by DMOs. Thus, it is 
unsurprising that resident-generated content may be considered as more trustworthy than content on DMO websites (see: Xiang \& Gretzel, 2010). Further, research on influencer marketing in relation to tourism shows that the fee paid to influencers has a direct negative effect on trust (see: Chatzigeorgiou, 2017). Hence, the value of residents' (organic) ambassadorial activities to DMOs cannot be overstated.

The residents playing an ambassadorial role in our study did not have a large number of followers in general, which is a key aspect (as well as their activities) in the effectiveness of social media influencers in the tourism context (Chatzigeorgiou, 2017). Although residents were found to have good local connectivity (majority of followers were from Onomichi), their wider reach (beyond the region and internationally) is important when the efficacy of their ambassadorial roles is concerned. Language is perhaps a major barrier in this respect, as international visitors are unlikely to follow (online) conversations in Japanese. Nevertheless, if the reach of residents acting as online place-brand ambassadors can be improved in terms of followers and beyond a certain geographical region, our findings suggest that residents' role can be a primary form of place marketing (instead of secondary communication of place image), especially with advancements in social media.

Our findings highlight that residents may take a more central and active role for promoting tourism in the digital age. Within the Japanese context, there is some precedence for residents' involvement in matters of local governance - the chonaikai system whereby residents act as an intermediary between local government (including police forces and fire departments) and specific neighborhoods (Suzuki, 2007). Although this is based on more of a top-down model of interaction, the Japanese sense of duty and collectivism may be a key feature in this system, which can be an advantage in the tourism context if effectively engaged. Consequently, another important change in the tourism marketing dynamics would be that the residents' role shifts from being passive targets of efforts to garner their support for tourism, to active and primary promoters of a place-brand. Such a shift in focus and importance is very salient for DMOs and local government agencies in not just promoting tourism, but also sustaining it in a manner that avoids phenomena such as "tourism phobia" and anti-tourist attitudes from emerging. As such, our findings have implications for locations in other parts of the world including Margate (UK), Barcelona (Spain), and Bologna (Italy). 


\section{Managerial implications}

The concept of DMOs was recognized and introduced in Japan relatively recently and is still at an early stage of development, especially regarding citizen participation. Hence, the primary marketing activities by DMOs in the Japanese context can be more advanced on social media. Particularly, the use of dedicated hashtags for main events (e.g. Minato Matsuri) would enable measurement of the effectiveness of promotional activities across social media, as well as better propagation of the promotional messages via place-brand ambassadors; for example, the Contributor and Retweeter ambassadors frequently retweeted informative tweets of DMOs, and therefore can serve as important links for DMOs on social media.

Although residents were better in promoting Onomichi (e.g. total number of ORTs by residents outnumbered those of DMOs and local media outlets), there are some areas where residents' role as place-ambassadors online could be developed. In the context of our study, the geographic reach of residents on Twitter was found to be rather limited. The resources of DMOs can be useful in this respect; for instance, DMOs' following vastly outnumbers that of residents. As such, DMOs may benefit by taking the initiative to identify and support key residents improve their social media skills, which would help residents gain more followers and increase their range as online place-brand ambassadors. Training may include technical aspects, but also more content-based training to help traverse language barriers and gain broader geographical following. In order to identify influential residents, DMOs can use social media analytics, including social network analyses, semantic analysis, as well as hashtags and content tracking.

Appropriate incentives can be determined based on the types of motivations we have identified. For example, residents motivated by 'Art and Play' can be engaged through showcasing their creative works as part of DMO initiatives to promote the uniqueness and cultural attractiveness of Onomichi. Others may be influenced by promoting small, occasional events. Increased community involvement from DMOs and specific social media events that showcase these could be valuable in building further links within and outside local communities, especially since residents as place-ambassadors exhibit high levels of identification with the place. Overall, we echo other researchers (Bokunewicz \& Shulman, 2017) in calling for DMOs to adopt a more nuanced and 
targeted approach to identifying and facilitating key influencers in their social media networks.

In addition to DMOs, local businesses and community organizations can also benefit from online place ambassadors. Local social clubs and leisure groups may particularly find it beneficial to connect with Hobbyists and Photographers, whereas business establishments (restaurants, cafes etc.) and Air BnB owners for example could advertise their services to visitors through Contributors. Featuring the recommendations of local residents in advertisements and marketing campaigns can be a more effective approach given that residents' endorsements can be viewed as more credible and authentic.

\section{Conclusion and avenues for further research}

This paper contributes to knowledge in tourism research by classifying the role of residents as place-brand ambassadors on social media, and by mapping their contributions based on their direct/indirect influence on (place) marketing, and the level of sentiment in the content generated by them. Previous research has classified travellers based on their social media usage (Amaro et al., 2016), but not residents, who are pivotal to sustainable tourism. Moreover, most previous studies focusing on residents have used self-reported data (e.g., Nunkoo \& Gursoy, 2012; Palmer et al., 2013; Strzelecka et al., 2017), whereas studies examining actual online activity are a rarity (see: Shakeela \& Weaver, 2012). Therefore, the current study addresses an important gap in the tourism literature.

Although we have attempted to justify our approach, the limitations of our study include the limited sample size of Twitter accounts, the restricted time-frame of analysis, and the fact that we focused only on the context of Onomichi. A detailed examination of the followers of the resident-ambassadors was also beyond the scope of our study. Nevertheless, further studies may replicate the approach detailed in this paper and examine other, unique, destination-settings worldwide, which may expose cultural divisions in residents' ambassadorial role, or alternatively, establish global behavioral parallels. In addition, since our study was limited to considering the Twitter activity of selected residents within the context of this study, future research may develop further insights by examining the nature and activity of followers (in the Twitter context) as well as residents. Particularly points of interest include, whether the followers of online 
place ambassadors are actual participants in events or visitors to a place, and in what ways they use Twitter and other social media for searching information on places to visit. Researchers may also undertake more in-depth comparisons between the contents of DMO activity on social media and that of residents in terms of their effect on potential tourists and other target groups. 


\section{References}

Akiya Saisei (2017). Onomichi Akiya Saisei Project. Retrieved November 27, 2017, from http://www.onomichisaisei.com

Amaro, S., Duarte, P., \& Henriques, C. (2016). Travelers' use of social media: A clustering approach. Annals of Tourism Research, 59, 1-15. doi: https://doi.org/10.1016/j.annals.2016.03.007

Arsal, I., Woosnam, K. M., Baldwin, E. D., \& Backman, S. J. (2010). Residents as travel destination information providers: An online community perspective. Journal of Travel Research, 49(4), 400-413. doi: https://doi.org/10.1177/0047287509346856

Bazeley, P., \& Jackson, K. (Eds.). (2013). Qualitative data analysis with NVivo. Sage Publications Limited.

BBC. (2015). Britain's seaside ruins. Retrieved June 10, 2018, from http://www.bbc.com/culture/story/20150609-britains-seaside-ruins

Bokunewicz, J. F., \& Shulman, J. (2017). Influencer identification in Twitter networks of destination marketing organizations. Journal of Hospitality and Tourism Technology, 8(2), 205-219. doi: 10.1108/JHTT-09-2016-0057

Boley, B. B., McGehee, N. G., Perdue, R. R., \& Long, P. (2014). Empowerment and resident attitudes toward tourism: Strengthening the theoretical foundation through a Weberian lens. Annals of Tourism Resarch, 49, 33-50. doi: https://doi.org/10.1016/j.annals.2014.08.005

Bonsón, E., \& Ratkai, M. (2013). A set of metrics to assess stakeholder engagement and social legitimacy on a corporate Facebook page. Online Information Review, 37(5), 787-803. https://doi.org/10.1108/OIR-03-2012-0054

Bonsón, E., Royo, S., \& Ratkai, M. (2015). Citizens' engagement on local governments' Facebook sites. An empirical analysis: The impact of different media and content types in Western Europe. Government Information Quarterly, 32(1), 52-62. doi: https://doi.org/10.1016/j.giq.2014.11.001

Braun, E., Kavaratzis, M., \& Zenker, S. (2013). My city - My brand: the different roles of residents in place branding. Journal of Place Management and Development, 6(1), 18-28. doi: https://doi.org/10.1108/17538331311306087

Chatzigeorgiou, C. (2017). Modelling the impact of social media influencers on behavioural intentions of millennials: The case of tourism in rural areas in Greece. Journal of Tourism, 3(2), 25-29. doi: 10.5281/zenodo.1209125

Coldwell, W. (2017). First Venice and Barcelona: now anti-tourism marches spread across Europe. Retrieved September 10, 2017, from https://www.theguardian.com/travel/2017/aug/10/anti-tourism-marches-spreadacross-europe-venice-barcelona

Dickinger, A., \& Költringer, C. (2011). Extracting destination representation and competitiveness from online content. Information Technology \& Tourism, 13(4), 327-339. doi: https://doi.org/10.3727/109830512X13364362859939

Freeman, R. E., \& McVea, J. (2001). A stakeholder approach to strategic management. SSRN Electronic Journal. doi: 10.2139/ssrn.263511 
Funck, C. (2008). Ageing tourists, ageing destinations: Tourism and demographic change in Japan. In F. Coulmas, H. Conrad, A. Schad-Seifert \& G. Vogt (Eds.), The Demographic Challenge: A Handbook about Japan. Online: Brill. doi: 10.1163/ej.9789004154773.i-1199.237

Govers, R., Go, F. M., \& Kumar, K. (2007). Virtual destination image a new measurement approach. Annals of Tourism Research, 34(4), 977-997. doi: https://doi.org/10.1016/j.annals.2007.06.001

Hannam, K., \& Knox, D. (2005). Discourse analysis in tourism research a critical perspective. Tourism Recreation Research, 30(2), 23-30. doi: https://doi.org/10.1080/02508281.2005.11081470

Horton, H. (2015). Japan has invented a "Google Maps"-style street view for cats Telegraph. Retrieved August 26, 2017, from http://www.telegraph.co.uk/news/worldnews/asia/japan/11843337/Japan-hasinvented-a-Google-Maps-style-street-view-for-cats.html

Jacobsen, J. K. S., \& Munar, A. M. (2012). Tourist information search and destination choice in a digital age. Tourism Management Perspectives, 1(1), 3947. doi: https://doi.org/10.1016/j.tmp.2011.12.005

Kang, M., \& Schuett, M. A. (2013). Determinants of sharing travel experiences in social media. Journal of Travel \& Tourism Marketing, 30(1-2), 93-107. doi: https://doi.org/10.1080/10548408.2013.751237

Kavaratzis, M. (2004). From city marketing to city branding: Towards a theoretical framework for developing city brands. Place Branding, 1(1), 58-73. doi: https://doi.org/10.1057/palgrave.pb.5990005

Kavaratzis, M. (2012). From "necessary evil" to necessity: stakeholders' involvement in place branding. Journal of Place Management and Development, 5(1), 7-19. doi: https://doi.org/10.1108/17538331211209013

Ketter, E., \& Avraham, E. (2012). The social revolution of place marketing: The growing power of users in social media campaigns. Place Branding and Public Diplomacy, 8(4), 285-294. doi: https://doi.org/10.1057/pb.2012.20

Kirilenko, A. P., \& Stepchenkova, S. O. (2017). Sochi 2014 Olympics on Twitter: Perspectives of hosts and guests. Tourism Management, 63, 54-65. doi: https://doi.org/10.1016/j.tourman.2017.06.007

Klijn, E.-H., Eshuis, J., \& Braun, E. (2012). The influence of stakeholder involvement on the effectiveness of place branding. Public Management Review, 14(4), 499519. doi: https://doi.org/10.1080/14719037.2011.649972

Költringer, C., \& Dickinger, A. (2015). Analyzing destination branding and image from online sources: A web content mining approach. Journal of Business Research, 68(9), 1836-1843. doi: https://doi.org/10.1016/j.jbusres.2015.01.011

Kotsi, F., Balakrishnan, M. S., Michael, I., \& Ramsoy, T. Z. (2016). Place branding: Aligning multiple stakeholder perception of visual and auditory communication elements. Journal of Destination Marketing and Management, 7, 112-130. doi: https://doi.org/10.1016/j.jdmm.2016.08.006

Kresl, P. K., \& letri, D. (2010). The Aging Population and the Competitiveness of Cities: Benefits to the Urban Economy. Edward Elgar Publishing: Cheltenham, 
UK.

Maheshwari, V., Lodorfos, G., \& Vandewalle, I. (2014). Exploring the role of stakeholders in place branding - a case analysis of the "City of Liverpool." International Journal of Business and Globalisation, 13(1), 104-121. doi: https://doi.org/10.1504//JBG.2014.063398

Mariani, M. M., \& Giorgio, L. (2017). The "Pink Night" festival revisited: Meta-events and the role of destination partnerships in staging event tourism. Annals of Tourism Research, 62(Supplement C), 89-109. doi: https://doi.org/10.1016/j.annals.2016.11.003

McLeay, F., Roberts, J., \& Yoganathan, V. (2012). Transferring social marketing knowledge through third sector CoPs. The Marketing Review, 12(4), 381-401. doi: http://dx.doi.org/10.1362/146934712X13469451716637

Ministry of Internal Affairs \& Communication (2015). Statistics Bureau: Population Data. [Online]. Retrieved September 27, 2018, from http://www.stat.go.jp/english/index.html.

Ministry of Land, Infrastructure, Transport \& Tourism (2016). 過疎地域等条件不利地 域における集落の現況把握調査 (Current situation investigation about settlements in disadvantaged areas such as depopulation areas). [Online]. Retrieved: September 27, 2018, from http://www.mlit.go.jp/common/001145930.pdf

Müller, J. M., Pommeranz, B., Weisser, J., \& Voigt, K.-I.. (2018). Digital, Social Media, and Mobile Marketing in industrial buying: Still in need of customer segmentation? Empirical evidence from Poland and Germany. Industrial Marketing Management, 73, 70-83. doi: 10.1016/j.indmarman.2018.01.033

Munar, A. M. (2011). Tourist-created content: rethinking destination branding. International Journal of Culture, Tourism and Hospitality Research, 5(3), 291305. doi: https://doi.org/10.1108/17506181111156989

Munar, A. M., \& Jacobsen, J. K. S. (2014). Motivations for sharing tourism experiences through social media. Tourism Management, 43, 46-54. doi: https://doi.org/10.1016/j.tourman.2014.01.012

Nunkoo, R., \& Gursoy, D. (2012). Residents' support for tourism. An identity perspective. Annals of Tourism Research, 39(1), 243-268. doi: https://doi.org/10.1016/j.annals.2011.05.006

Nunkoo, R., \& Ramkissoon, H. (2012). Power, trust, social exchange and community support. Annals of Tourism Research, 39(2), 997-1023. doi: https://doi.org/10.1016/j.annals.2011.11.017

Nunkoo, R., \& So, K. K. F. (2016). Residents' support for tourism: Testing alternative structural models. Journal of Travel Research, 55(7), 847-861. doi: https://doi.org/10.1177/0047287515592972

Okazaki, S., Díaz-Martín, A. M., Rozano, M., \& Menéndez-Benito, H. D. (2015). Using Twitter to engage with customers: A data mining approach. Internet Research, 25(3), 416-434. doi: https://doi.org/10.1108/IntR-11-2013-0249

Palmer, A., Koenig-Lewis, N., \& Jones, L. E. M. (2013). The effects of residents' social identity and involvement on their advocacy of incoming tourism. Tourism 
Management, 38, 142-151. doi: https://doi.org/10.1016/j.tourman.2013.02.019

Rausch, A. (2015). Regionalism and the local. In J. D. Babb (Ed.), The Sage handbook of modern Japanese studies (pp. 148-165). London: Sage.

Rogers, R. (2013). Debanalizing Twitter: The transformation of an object of study. In Proceedings of the 5th Annual ACM Web Science Conference on - WebSci '13 (pp. 356-365). New York, New York, USA: ACM Press.

Ryan, C. (2000). Tourist experiences, phenomenographic analysis, post-postivism and neural network software. The International Journal of Tourism Research, 2(2), 119-131. doi: https://doi.org/10.1002/(SICI)15221970(200003/04)2:2<119::AID-JTR193>3.0.CO;2-G

Salas-Olmedo, M. H., Moya-Gómez, B., García-Palomares, J. C., \& Gutiérrez, J. (2018). Tourists' digital footprint in cities: Comparing Big Data sources. Tourism Management, 66, 13-25. doi: https://doi.org/10.1016/j.tourman.2017.11.001

Schreier, M. (2012). Qualitative content analysis in practice. Sage Publications.

Sevin, E. (2013). Places going viral: Twitter usage patterns in destination marketing and place branding. Journal of Place Management and Development, 6(3), 227239. doi: https://doi.org/10.1108/JPMD-10-2012-0037

Shakeela, A., \& Weaver, D. (2012). Resident reactions to a tourism incident: Mapping a Maldivian Emoscape. Annals of Tourism Research, 39(3), 13371358. doi: https://doi.org/10.1016/j.annals.2012.01.007

Smith, A. N., Fischer, E., \& Yongjian, C. (2012). How does brand-related UserGenerated Content differ across YouTube, Facebook, and Twitter? Journal of Interactive Marketing, 26(2), 102-113. doi: https://doi.org/10.1016/j.intmar.2012.01.002

Stepchenkova, S., Kirilenko, A. P., Morrison, A. M., \& Gabr, H. (2009). Facilitating content analysis in tourism research. Journal of Travel Research, 47(4), 454469. doi: https://doi.org/10.1177/0047287508326509

Strzelecka, M., Boley, B. B., \& Woosnam, K. M. (2017). Place attachment and empowerment: Do residents need to be attached to be empowered? Annals of Tourism Research, 66, 61-73. doi: https://doi.org/10.1016/j.annals.2017.06.002

Stylidis, D., Belhassen, Y., \& Shani, A. (2015). Three tales of a city: Stakeholders' images of Eilat as a tourist destination. Journal of Travel Research, 54(6), 702716. doi: https://doi.org/10.1177/0047287514532373

Stylidis, D., Shani, A., \& Belhassen, Y. (2017). Testing an integrated destination image model across residents and tourists. Tourism Management, 58, 184-195. doi: https://doi.org/10.1016/j.tourman.2016.10.014

Stylidis, D., Sit, J., \& Biran, A. (2016). An exploratory study of residents' perception of place image: The case of Kavala. Journal of Travel Research, 55(5), 659674. doi: https://doi.org/10.1177/0047287514563163

Suzuki, Y. (2007). Chonaikai. In G. Ritzer (Ed.), In The Blackwell Encyclopedia of Sociology. Online: Wiley. doi: 10.1002/9781405165518.wbeosc033

Tajfel, H., \& Turner, J. C. (1979). An integrative theory of intergroup conflict. In W. G. Austin \& S. Worchel (Eds.), The Social Psychology of Intergroup Relations (pp. 
33-47). Monterey: Brookes/Cole.

Thibaut, J. W., \& Kelley, H. H. (1959). The social psychology of groups. New York: Wiley.

Toubia, O., \& Stephen, A. (2013). Intrinsic vs. Image-Related Utility in Social Media: Why Do People Contribute Content to Twitter? Marketing Science, 32(3), 368392. doi: $10.1287 / \mathrm{mksc} .2013 .0773$

Ward, J. (2018). Down by the sea: visual arts, artists and coastal regeneration. International Journal of Cultural Policy, 24(1), 121-138. doi: 10.1080/10286632.2016.1153080

Williams, N. L., Inversini, A., Buhalis, D, \& Ferdinand, N. (2015). Community crosstalk: an exploratory analysis of destination and festival eWOM on Twitter. Journal of Marketing Management, 31(9-10), 1-28. doi: 10.1080/0267257X.2015.1035308

Wong, K. (2017). Japan's Social Media Landscape in 2017 | freshtrax by btrax. Retrieved August 26, 2017, from http://blog.btrax.com/en/2017/01/30/japanssocial-media-landscape-2017/

Xiang, Z., \& Gretzel, U. (2010). Role of social media in online travel information search. Tourism Management, 31(2), 179-188. doi: https://doi.org/10.1016/j.tourman.2009.02.016

Young, C. A., Corsun, D. L., \& Beloglu, S. (2007). A taxonomy of hosts: Visiting friends and relatives. Annals of Tourism Research, 34(2), 497-516. doi: https://doi.org/10.1016/j.annals.2006.12.003

Zeng, B., \& Gerritsen, R. (2014). What do we know about social media in tourism? A review. Tourism Management Perspectives, 10, 27-36. doi: https://doi.org/10.1016/j.tmp.2014.01.001

Zenker, S., \& Beckmann, S. C. (2013). My place is not your place - different place brand knowledge by different target groups. Journal of Place Management and Development, 6(1), 6-17. doi: https://doi.org/10.1108/17538331311306078

Zenker, S., Braun, E., \& Petersen, S. (2017). Branding the destination versus the place: The effects of brand complexity and identification for residents and visitors. Tourism Management, 15-27. doi:

https://doi.org/10.1016/j.tourman.2016.10.008 
Appendix A: Information on the Twitter accounts analyzed

\begin{tabular}{|c|c|c|c|c|c|c|c|c|c|c|}
\hline $\begin{array}{l}\text { A/C } \\
\text { No }\end{array}$ & \#ORTs & $\begin{array}{l}\text { ORT } \\
\text { cove- } \\
\text { rage }\end{array}$ & $\begin{array}{c}\text { May } \\
\text { tweets }\end{array}$ & $\begin{array}{c}\# \text { OM } \\
\text { in } \\
\text { profile }\end{array}$ & $\begin{array}{l}\text { OM in } \\
\text { cover } \\
\text { photo? }\end{array}$ & $\begin{array}{c}\text { OM } \\
\text { followers }\end{array}$ & followers & following & $\begin{array}{c}\text { All } \\
\text { tweets }\end{array}$ & Likes \\
\hline 1 & 89 & $12 \%$ & 721 & 5 & yes & 23 & 2514 & 2202 & 4625 & 142564 \\
\hline 2 & 3 & $19 \%$ & 16 & 0 & no & 52 & 787 & 369 & 6759 & 167 \\
\hline 3 & 1 & $5 \%$ & 19 & 1 & no & 12 & 117 & 127 & 10992 & 12 \\
\hline 4 & 78 & $35 \%$ & 224 & 0 & yes & 19 & 94 & 189 & 2527 & 5545 \\
\hline 5 & 45 & $34 \%$ & 132 & 1 & yes & 5 & 268 & 237 & 6772 & 934 \\
\hline 6 & 4 & $2 \%$ & 208 & 0 & yes & 14 & 338 & 451 & 15772 & 98 \\
\hline 7 & 31 & $19 \%$ & 165 & 1 & no & 16 & 572 & 1428 & 5305 & 49 \\
\hline 8 & 41 & $6 \%$ & 745 & 2 & no & 66 & 798 & 1180 & 42876 & 15356 \\
\hline 9 & 3 & $1 \%$ & 254 & 0 & no & 2 & 150 & 175 & 25123 & 78 \\
\hline 10 & 0 & $0 \%$ & 63 & 0 & no & 3 & 317 & 348 & 19889 & 3825 \\
\hline 11 & 47 & $55 \%$ & 85 & 4 & yes & 22 & 1094 & 1150 & 34354 & 5798 \\
\hline 12 & 4 & $4 \%$ & 98 & 2 & yes & 0 & 36 & 23 & 5992 & 188 \\
\hline 13 & 48 & $15 \%$ & 311 & 3 & yes & 8 & 189 & 143 & 1421 & 3764 \\
\hline 14 & 0 & $0 \%$ & 1 & 2 & no & 8 & 100 & 69 & 2580 & 5 \\
\hline 15 & 7 & $19 \%$ & 37 & 1 & no & 81 & 597 & 178 & 8798 & 31 \\
\hline 16 & 93 & $61 \%$ & 153 & 0 & no & 3 & 134 & 148 & 22512 & 504 \\
\hline 17 & 2 & $11 \%$ & 19 & 2 & - & 3 & 201 & 240 & 10556 & 676 \\
\hline 18 & 2 & $6 \%$ & 35 & 2 & no & 39 & 884 & 434 & 3153 & 42 \\
\hline 19 & 4 & $50 \%$ & 8 & 1 & yes & 16 & 377 & 333 & 1972 & 14285 \\
\hline 20 & 2 & $18 \%$ & 11 & 1 & no & 5 & 203 & 161 & 2146 & 244 \\
\hline 21 & 191 & $52 \%$ & 367 & 1 & no & 1 & 354 & 658 & 2612 & 203 \\
\hline 22 & 0 & $0 \%$ & 5 & 1 & yes & 16 & 152 & 480 & 3470 & 17 \\
\hline 23 & 14 & $6 \%$ & 230 & 1 & no & 1 & 523 & 513 & 1503 & 3729 \\
\hline 24 & 17 & $8 \%$ & 205 & 0 & no & 5 & 63 & 115 & 24941 & 3416 \\
\hline 25 & 13 & $3 \%$ & 394 & 1 & - & 31 & 540 & 467 & 83750 & 850 \\
\hline 26 & 0 & $0 \%$ & 2 & 1 & no & 18 & 427 & 645 & 1411 & 14 \\
\hline 27 & 19 & $100 \%$ & 19 & 2 & yes & 34 & 163 & 195 & 1900 & 47 \\
\hline 28 & 5 & $63 \%$ & 8 & 1 & no & 34 & 206 & 204 & 2723 & 40 \\
\hline 29 & 1 & $1 \%$ & 175 & 1 & no & 74 & 1561 & 409 & 34807 & 3340 \\
\hline 30 & 8 & $4 \%$ & 186 & 0 & no & 8 & 710 & 395 & 4196 & 7254 \\
\hline 31 & 51 & $16 \%$ & 321 & 0 & yes & 1 & 104 & 50 & 7887 & 160 \\
\hline 32 & 10 & $21 \%$ & 47 & 3 & yes & 11 & 203 & 357 & 5316 & 214 \\
\hline 33 & 130 & $15 \%$ & 844 & 4 & yes & 170 & 864 & 929 & 31038 & 1845 \\
\hline 34 & 308 & $36 \%$ & 861 & 6 & - & 48 & 817 & 1279 & 7953 & 9146 \\
\hline 35 & 71 & $63 \%$ & 112 & 1 & yes & 160 & 2042 & 516 & 11359 & 0 \\
\hline 36 & 8 & $22 \%$ & 37 & 0 & no & 25 & 126 & 74 & 4023 & 36 \\
\hline 37 & 124 & $74 \%$ & 168 & 1 & - & 131 & 2342 & 1940 & 15049 & 1148 \\
\hline 38 & 3 & $6 \%$ & 49 & 1 & yes & 19 & 6265 & 469 & 13007 & 3641 \\
\hline 39 & 0 & $0 \%$ & 20 & 0 & no & 31 & 1254 & 795 & 9847 & 3205 \\
\hline 40 & 58 & $31 \%$ & 187 & 6 & no & 30 & 897 & 252 & 34031 & 123 \\
\hline 41 & 0 & $0 \%$ & 4 & 1 & no & 30 & 414 & 347 & 1958 & 341 \\
\hline 42 & 1 & $2 \%$ & 54 & 1 & no & 11 & 158 & 332 & 2413 & 1035 \\
\hline 43 & 8 & $2 \%$ & 405 & 0 & no & 2 & 83 & 57 & 22311 & 3 \\
\hline 44 & 17 & $52 \%$ & 33 & 0 & no & 4 & 94 & 75 & 5699 & 6581 \\
\hline
\end{tabular}




\section{Appendix B. Coding categories of ORT topics.}

\begin{tabular}{|c|c|}
\hline \multicolumn{2}{|l|}{ Area Name } \\
\hline A1 (Onomichi) & City name \\
\hline A2 (Island names) & Island name \\
\hline A3 (Area name) & Area name \\
\hline \multicolumn{2}{|c|}{ Physical Environment and Weather } \\
\hline P1 (Scenery) & Area or Scenery related (Shimanami Islands, Ocean, Cycling road, Hills) \\
\hline P2 (Architecture) & Architecture (Old houses) \& Historic sites (Temples) \\
\hline P3 (Weather) & Weather \\
\hline \multicolumn{2}{|l|}{$\begin{array}{l}\text { Community } \\
\text { Services }\end{array}$} \\
\hline C1 (Local services) & Local government, Public services, Public transportation \\
\hline C2 (School) & School (University, High school, Junior high, Elementary) related \\
\hline C3 (Business) & Business, Business association etc \\
\hline \multicolumn{2}{|c|}{ Entertainment Services } \\
\hline E1 (Gourmet) & Restaurants \& Bar \\
\hline E2 (Lifestyle) & Leisure (Golf course, Hot spring), Beauty (Hair Salon), Lessons (Dance) \\
\hline E3 (Culture) & Music (Live House), Cinema, Art (Museum) \\
\hline E4 (Event) & Event \& Festival \\
\hline E5 (Shopping) & Place to shop, Souvenir shop \\
\hline \multicolumn{2}{|l|}{ Social Environment } \\
\hline $\begin{array}{l}\text { S1 (Community } \\
\text { group) }\end{array}$ & Hobby Group, NPO, Volunteer \\
\hline S2 (Local media) & Local Media (Newspaper, Radio, Free Magazine, Web) \\
\hline S3 (Celebrity) & Celebrity \& Public people (Politician, Mayor, Officer, Artist) \\
\hline \multicolumn{2}{|r|}{ 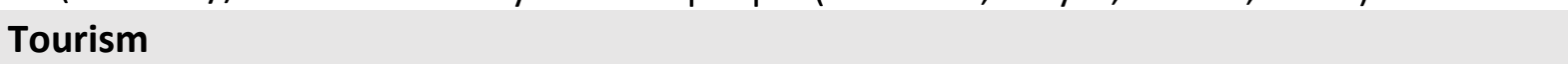 } \\
\hline T1 (Specialty) & Specialty \& Souvenir (Lemon, Seafood products) \\
\hline T2 (Tourism) & Tourism (Hotel, Guest house) \\
\hline T3 (DMOs) & DMO \\
\hline \multicolumn{2}{|l|}{ Special Events } \\
\hline \multicolumn{2}{|l|}{ O1 (Minato } \\
\hline Matsuri) & Minato Matsuri \\
\hline $\mathrm{O} 2$ (TV broadcast) & TV program "BraTamori" \\
\hline O3 (Station closing) & Station building closing ceremony \\
\hline O4 (Golden Week) & Golden Week \\
\hline O5 (Cat) & Neco Mamire / Neco matsuri (Onomichi museum) \\
\hline
\end{tabular}




\section{Appendix C: Word frequency test results for DMOs}

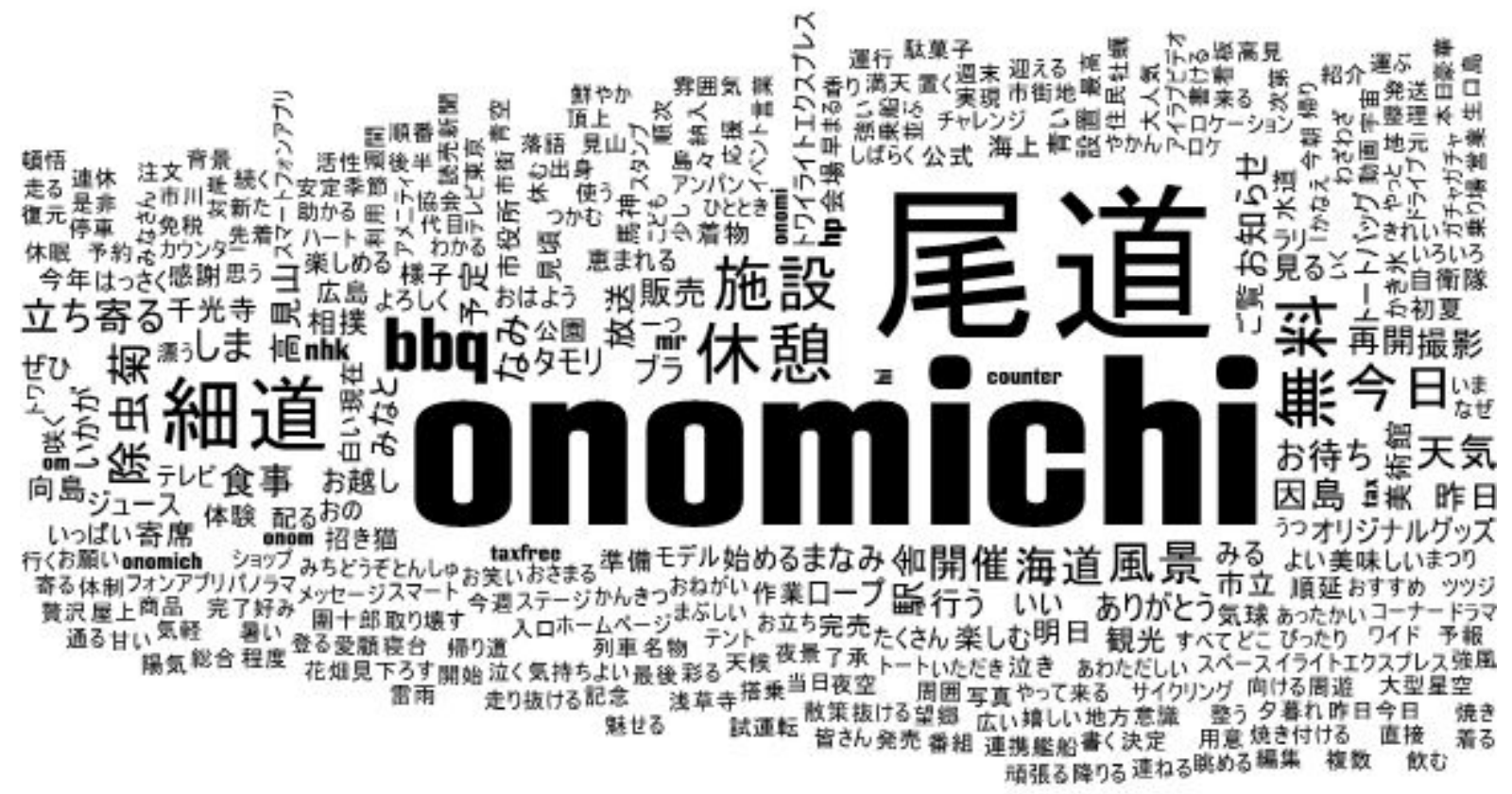




\section{Appendix D. Examples of typical tweets for different intentions.}

1) Advertisement

"RT@***【Announcement】The Onomichi City Museum of Art is planning to resume the sales of "Calico cat tote bag", which is now out of stock, on 22nd May (Mon)."

\section{2) Suggestion}

(a) Information propagation

"It seems the airdate of Bla Tamori, which Tamori visited Onomichi for the shoot the other day, has been set . It will be aired on channel NHK from 7:30 on the 20th of May . They might show someone you know ? lol"

(b) Onomichi representative

"Dear everyone who watched "Bla Tamori" today. It'd be my pleasure if you took a cue from this to get interested in Onomichi, which you might not have known well. If you've missed the programme, there will be a rerun at the end of the month. Please don't miss out."

(c1) Advocating retweet by residents

RT @***: Onomichi is a great place!! If you live out in a suburb, you'll need a car. But in a way, it's suitable for raising kids.

(c2) Advocating retweet by tourists

RT @***: Innoshima was a truly lovely and amazing Island!!

3) Description

"A volunteer group, organized for the purpose of helping foreign tourists in English ... made hand-made signboards of tourism information in English."

4) Impression

"I can't help but feel deep nostalgia and loneliness on the disappearance of the building I have been long accustomed to since I was born and the transformation of my hometown."

5) Art \& Play

"Cloudy sky today

While watching yacht

Having a sandwich from "Fururu" for lunch

Good afternoon, Onomichi.

\#NowSky \#Fururu \#Onomichi (in Japanese) \#onomiti (misspelling of Onomichi in English)\#***\#***"

6) $Q \& A$ conversation

"@***Yes, the cat festival has started, and many tourists are walking around here. The "Cat Alley" should be pretty bustling ."

7) Daily Chat 
"2076 L with 4א" (a rare goods train) has confirmed to pass through the Onomichi station."

\section{8) Negative tweets}

"@*** Probably, the number of visitors from other prefectures to Onomichi is highest during GW(Golden Week holidays). But there's still not as many people compared to the normal situation in the urban area:) A lack of parking space, however, might cause some problems." 


\section{Appendix E: Most frequent hashtags}

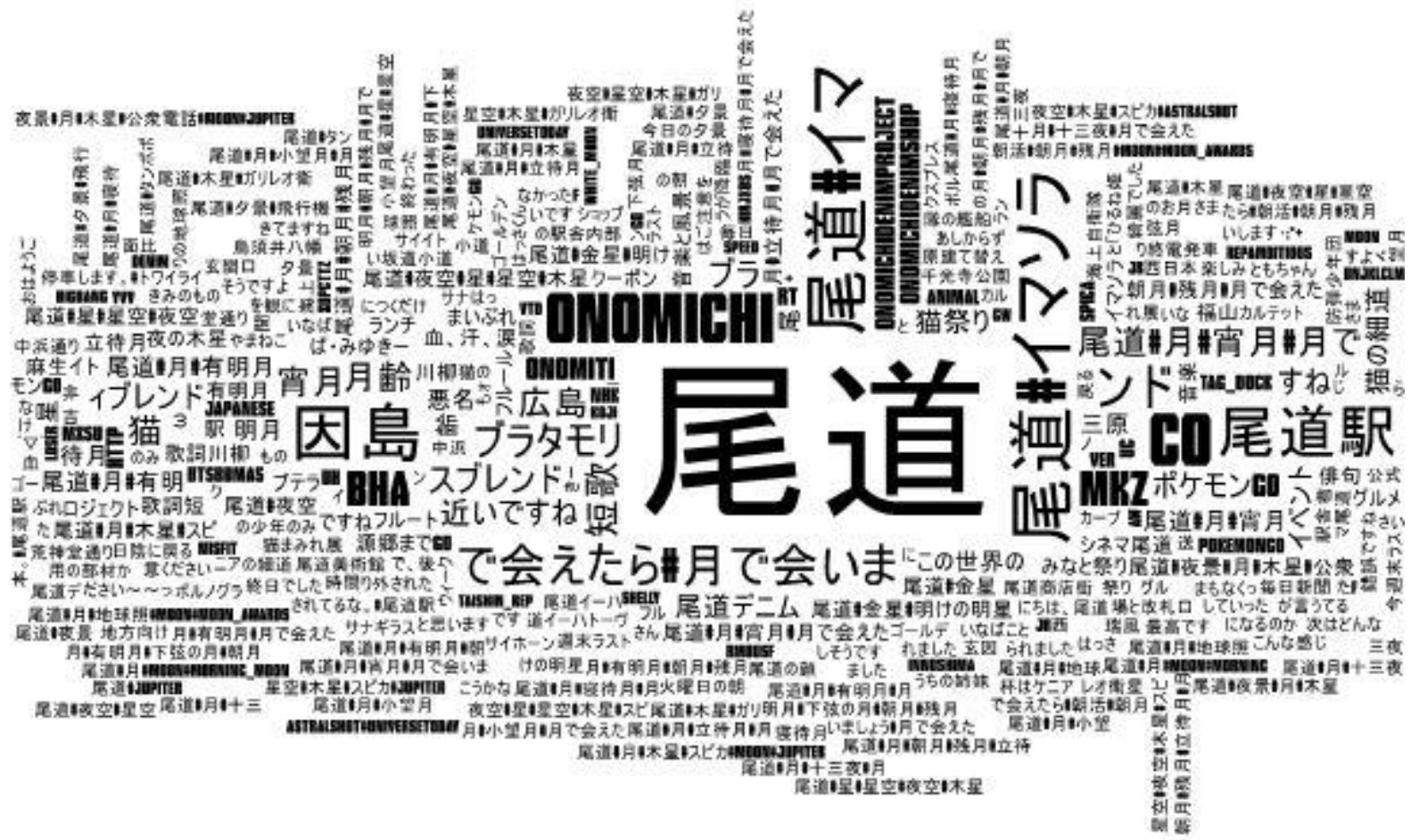

